\title{
PENGEMBANGAN LEMBAR KERJA SISWA (LKS) UNTUK MATERI MICROSOFT ACCESS DI KELAS XI SMA NEGERI 3 SINGARAJA
}

\author{
Oleh \\ Putu Melly Soliastini \\ Jurusan Pendidikan Teknik Informatika, FTK, UNDIKSHA
}

\begin{abstract}
ABSTRAK
Penelitian ini bertujuan untuk (1) merancang dan mengimplementasikan pengembangan LKS untuk materi Microsoft Access di SMA Negeri 3 Singaraja; (2) mengetahui respon siswa kelas XI SMA Negeri 3 Singaraja terhadap pengembangan LKS untuk materi Microsoft Access.

Jenis penelitian yang digunakan adalah Penelitian dan Pengembangan (Research and Development / R\&D) dengan model pengembangan Dick and Carey. Penelitian ini melibatkan siswa kelas XI-IPA 1 SMA Negeri 3 Singaraja tahun ajaran 2009/2010. Data tentang sumber belajar siswa diperoleh dengan menggunakan wawancara dan angket. Data tentang karakteristik siswa, kevalidan LKS serta respon siswa diperoleh dengan menggunakan angket. Data yang diperoleh tersebut dianalisis secara deskriptif.

Hasil analisis data respon siswa menunjukkan bahwa persentase siswa yang memberikan respon sangat positif sebesar $77,5 \%$, persentase siswa yang memberikan respon positif sebesar $22,5 \%$ dan tidak ada siswa yang memberikan respon ragu-ragu, negatif maupun sangat negatif. Skor rata-rata respon siswa yang diperoleh adalah sebesar 82,05. Skor tersebut menunjukkan bahwa respon siswa terhadap pengembangan LKS untuk materi Microsoft Access berada pada kategori sangat positif.
\end{abstract}

Kata-kata kunci: pengembangan, LKS, Microsoft Access

\begin{abstract}
The purposes of this research are: firstly to design and to implement the development of student's worksheet for Microsoft Access subject at SMA N 3 Singaraja, and the second one is to know the responses of the student in grade XI of SMA N 3 Singaraja toward the development of student's worksheet for Microsoft Access subject.

The kind of research which is used in this research is Research and Development or R\&D and through the development of Dick and Carey model. This research is involving the student of grade XI-IPA 1 of SMA N 3 Singaraja at 2009. 2010 of academic period. The data about the student's resource is got from the interview and questionnaires. The data about the students' characteristic, the
\end{abstract}


validities of student's worksheet, and the student responses are got by questionnaires. The data were analyzed descriptively.

The analysis' result of the students' responses show the student percentage which are giving excellent positive responses are about 77,5\%, positive responses are about $22,5 \%$, and there are no students who gave bad or no responses. The average score of the students response is 82,05. This score show the student response of the development of student's worksheet in Microsoft Access material is in good positive response.

Keywords: development, student's worksheet, Microsoft Access

\section{PENDAHULUAN}

Belajar merupakan proses mental yang terjadi dalam diri seseorang sehingga menyebabkan munculnya perubahan prilaku dan penambahan pengetahuan (Wina Sanjaya, 2008:112). Mengajar adalah proses membimbing kegiatan belajar. Kegiatan mengajar hanya akan bermakna bila terjadi kegiatan belajar siswa (Oemar Hamalik, 1994:36). Dalam proses belajar mengajar (PBM) akan terjadi interaksi antara peserta didik dan pendidik. Keberhasilan proses belajar mengajar tidak terlepas dari cara pendidik mengajar dan peserta didik belajar.

Berdasarkan hasil wawancara yang dilakukan penulis dengan guru mata pelajaran TIK, pembelajaran TIK di SMA Negeri 3 Singaraja sudah berjalan baik namun keberhasilan belajar siswa masih belum optimal. Hal ini disebabkan oleh beberapa hal diantaranya adalah belum optimalnya penggunaan komputer, proses pembelajaran yang diterapkan di sekolah cenderung berpusat pada guru, dan belum tersedianya sumber belajar seperti Lembar Kerja Siswa (LKS) bagi siswa.

Belum optimalnya hasil belajar siswa di SMA Negeri 3 Singaraja dapat dilihat dari masih terdapatnya siswa yang nilainya dibawah Kriteria Ketuntasan Minimal (KKM) yang ditetapkan sekolah sebesar 75. Salah satu materi yang paling sering mengalami ketuntasan belajar belum optimal adalah Microsoft Access. Hal ini dapat dilihat pada tabel 1 . 
Tabel 1. Data hasil belajar siswa kelas XI-IPA1 pada materi Microsoft Access (Sumber: Arsip Hasil Belajar Siswa Kelas XI-IPA1 SMA N 3 Singaraja)

\begin{tabular}{|c|c|c|c|c|}
\hline \multirow{2}{*}{ Tahun Ajaran } & \multirow{2}{*}{ Rata-Rata } & \multirow{2}{*}{$\begin{array}{c}\text { Ketuntasan } \\
(\%)\end{array}$} & \multicolumn{2}{|c|}{ Jumlah Siswa } \\
\cline { 3 - 5 } & & 50 & 20 orang & 20 orang \\
\hline $2008 / 2009$ & 74,47 & 5 . &
\end{tabular}

Tabel tersebut menunjukkan bahwa rata-rata hasil belajar siswa kelas XI-IPA1 pada materi Microsoft Access pada tahun ajaran 2008/2009 hanya 74,47, sedangkan untuk persentase ketuntasannya hanya mencapai $50 \%$, dimana jumlah siswa yang tuntas hanya 20 orang dari 40 siswa. Hal tersebut tentunya menunjukkan bahwa standar ketuntasan minimal sebesar $75 \%$ belum terpenuhi.

Untuk mengatasi permasalahan tersebut, berbagai upaya telah dilakukan guru diantaranya dengan mengubah metode mengajarnya di kelas. Guru yang pada awalnya cenderung menggunakan metode ceramah, mencoba beralih menggunakan metode demonstrasi dan penugasan. Metode demonstrasi digunakan bertujuan untuk membuat pelajaran menjadi lebih jelas dan konkret. Metode pemberian tugas digunakan bertujuan untuk memberi kesempatan kepada siswa agar dapat lebih banyak belajar melalui latihan-latihan yang diberikan guru, tetapi pada kenyataannya hasil belajar siswa masih tetap rendah. Setelah permasalahan tersebut dikaji kembali, dapat dikatakan bahwa keberhasilan dari suatu proses pembelajaran tidak hanya ditentukan oleh metode mengajar yang digunakan oleh pendidik tetapi juga harus didukung oleh sumber belajar yang memadai.

Untuk mengatasi permasalahan tersebut, maka salah satu usaha yang dilakukan penulis adalah dengan menyediakan sumber belajar berupa Lembar Kerja Siswa (LKS). Lembar Kerja Siswa (LKS) ialah lembar kerja yang berisi informasi dan perintah/instruksi dari guru kepada siswa untuk mengerjakan suatu kegiatan belajar dalam bentuk kerja, praktek, atau dalam bentuk penerapan hasil belajar untuk mencapai suatu tujuan (Bulu,1993:8). Jenis LKS yang dikembangkan adalah LKS berstruktur. Indrianto (dalam Romusha, 2007:6) mengemukakan LKS berstruktur merupakan LKS memuat informasi, contoh dan tugas-tugas. LKS tersebut dapat dimanfaatkan siswa sebagai sumber belajar dengan atau tanpa bimbingan guru 
dalam mencapai tujuan pembelajaran, akan tetapi LKS tidak dapat menggantikan peran guru dalam kelas. Melalui pengembangan LKS, diharapkan keberhasilan siswa dalam belajar dapat tercapai dengan optimal.

Berdasarkan latar belakang masalah tersebut, maka penulis ingin mengembangkan LKS melalui sebuah penelitian yang berjudul "Pengembangan Lembar Kerja Siswa (LKS) Untuk Materi Microsoft Access Di Kelas XI SMA Negeri 3 Singaraja".

\section{METODE PENELITIAN}

Jenis penelitian yang digunakan adalah Penelitian dan Pengembangan (Research and Development / $R \& D$ ) dengan model pengembangan Dick And Carey. Instrumen yang digunakan dalam penelitian ini berupa pertanyaan wawancara dan angket. Data yang dikumpulkan untuk dianalisis dalam penelitian ini meliputi informasi tentang sumber belajar, karakteristik siswa, data kevalidan LKS serta respon siswa terhadap LKS yang dikembangkan. Untuk lebih jelasnya dapat dilihat pada tabel 2 .

Tabel 2. Teknik Pengumpulan Data

\begin{tabular}{|c|l|l|l|l|}
\hline No & \multicolumn{1}{|c|}{ Jenis Data } & \multicolumn{1}{|c|}{ Metode } & $\begin{array}{l}\text { Alat pengumpulan } \\
\text { data }\end{array}$ & \multicolumn{1}{|c|}{ Sumber data } \\
\hline 1 & $\begin{array}{l}\text { Informasi tentang } \\
\text { sumber belajar }\end{array}$ & $\begin{array}{l}\text { Wawancara, } \\
\text { angket }\end{array}$ & $\begin{array}{l}\text { Pertanyaan } \\
\text { wawancara, } \\
\text { angket }\end{array}$ & $\begin{array}{l}\text { Guru mata } \\
\text { pelajaran TIK, } \\
\text { siswa }\end{array}$ \\
\hline 2 & Karakteristik siswa & Angket & Angket & Siswa \\
\hline 3 & Kevalidan LKS & Angket & Angket & Ahli \\
\hline 4 & Respon siswa & Angket & Angket & Siswa \\
\hline
\end{tabular}

Data mengenai sumber belajar, karakteristik siswa, dan kevalidan LKS dianalisis secara deskriptif kualitatif. Data respon siswa dianalisis secara deskriptif kuantitatif. Analisis data respon siswa didasarkan pada rata-rata kelas $(\bar{X})$ dari respon siswa, Mean Ideal (MI), dan Standar Deviasi Ideal (SDI).

Rata-rata kelas dari skor respon siswa dihitung dengan rumus: 


$$
\bar{X}=\frac{\sum X}{N}
$$

Keterangan :

$$
\begin{array}{ll}
\bar{X} & =\text { Rata-rata kelas untuk skor respon siswa } \\
\sum X & =\text { Jumlah skor respon siswa } \\
\mathrm{N} \quad & =\text { Banyaknya siswa }
\end{array}
$$

Rumus untuk MI dan SDI adalah sebagai berikut.

$$
\begin{aligned}
& M I=\frac{1}{2}(\text { skor tertinggi ideal }+ \text { skor terendah ideal }) . . \\
& S D I=\frac{1}{6}(\text { skor tertinggideal }- \text { skor terendah ideal })
\end{aligned}
$$

Rata-rata kelas $(\bar{X})$ dari skor respon siswa kemudian dikategorikan dengan menggunakan pedoman seperti pada tabel 3.

Tabel 3. Kriteria Penggolongan Respon Siswa (Nurkancana dan Sunartana (dalam Kusumayuningsih, 2005:55))

\begin{tabular}{|c|l|l|}
\hline No & \multicolumn{1}{|c|}{ Interval } & \multicolumn{1}{c|}{ Kategori } \\
\hline 1 & $\mathrm{MI}+1,5 \mathrm{SDI} \leq \bar{X}$ & Sangat positif \\
\hline 2 & $\mathrm{MI}+0,5 \mathrm{SDI} \leq \bar{X}<\mathrm{MI}+1,5 \mathrm{SDI}$ & Positif \\
\hline 3 & $\mathrm{MI}-0,5 \mathrm{SDI} \leq \bar{X}<\mathrm{MI}+0,5 \mathrm{SDI}$ & Ragu-ragu \\
\hline 4 & $\mathrm{MI}-1,5 \mathrm{SDI} \leq \bar{X}<\mathrm{MI}-0,5 \mathrm{SDI}$ & Negatif \\
\hline 5 & $\bar{X}<\mathrm{MI}-1,5 \mathrm{SDI}$ & Sangat negatif \\
\hline
\end{tabular}

\section{HASIL DAN PEMBAHASAN}

Hasil pengembangan LKS untuk materi Microsoft Access dalam penelitian ini melalui beberapa tahap yaitu penentuan mata pelajaran sebagai objek pengembangan, analisis kebutuhan, proses pengembangan draft, penyusunan draft pengembangan serta tinjauan ahli dan uji coba.

Pada tahap penentuan mata pelajaran sebagai objek pengembangan, mata pelajaran yang dipilih adalah mata pelajaran TIK khususnya materi Microsoft Access. 
Pada tahap analisis kebutuhan diperoleh data yang menunjukkan bahwa dari 84 orang siswa yang sudah memiliki buku, sebesar $68 \%$ siswa menyatakan buku tersebut sudah dilengkapi dengan pemaparan langkah-langkah kerja yang jelas, sebesar $51 \%$ siswa menyatakan buku tersebut hanya dilengkapi dengan soal yang bersifat teoritis saja, sebesar $81 \%$ siswa menyatakan buku tersebut sudah dilengkapi dengan soal pratikum, serta hanya sebesar 64\% siswa menyatakan buku tersebut sudah dapat membantu dalam memahami materi. Data tersebut menunjukkan sebagian siswa kelas XI di SMA Negeri 3 Singaraja sudah menggunakan buku dalam proses pembelajaran TIK khususnya untuk materi Microsoft Access. Buku tersebut sudah dilengkapi dengan soal-soal teori maupun praktek, akan tetapi pemaparan materinya dianggap belum begitu jelas bagi siswa, sehingga tidak semua siswa merasa terbantu dalam memahami materi Microsoft Access. Hal tersebut menyebabkan siswa merasa memerlukan suatu sumber belajar tambahan yang dapat dijadikan pedoman dalam proses pembelajaran TIK.

Pada tahap proses pengembangan draft dilakukan analisis kondisi pembelajaran dan langkah pengembangan.

\section{Analisis Kondisi Pembelajaran}

Analisis kondisi pembelajaran yang dilakukan dalam proses pengembangan draft adalah sebagai berikut.

a. Analisis tujuan dan karakteristik mata pelajaran

Materi Microsoft Access yang diajarkan di SMA Negeri 3 Singaraja bertujuan untuk memberikan pengetahuan database kepada siswa serta memberikan kemampuan kepada siswa untuk membuat dan mengolah file menggunakan program database. Karakteristik dari materi Microsoft Access lebih banyak berfokus pada kegiatan praktek dalam pencapaian kompetensinya. Dari tujuan dan karakteristik materi Microsoft Access tersebut, maka dikembangkan suatu bahan ajar yang penyajian materinya menggabungkan antara teori dan praktek.

b. Analisis sumber belajar

Berdasarkan hasil wawancara dengan salah seorang guru TIK di SMA Negeri 3 Singaraja, dalam proses pembelajaran TIK sudah menggunakan buku 
referensi tetapi belum semua siswa memiliki buku tersebut. Hal ini juga dapat dilihat dari persentase siswa yang memiliki sumber belajar berupa buku hanya sebesar $52 \%$ yaitu sebanyak 84 orang siswa dan yang belum memiliki buku sebesar $48 \%$ yaitu sebanyak 78 orang siswa. Selain menggunakan buku referensi tersebut, guru juga biasanya mencari materi dari internet, tetapi materi yang diperoleh seringkali tidak sesuai dengan tuntutan pencapaian kompetensi.

Dari permasalahan tersebut, maka penulis mengembangkan sumber belajar berupa LKS khususnya untuk materi Microsoft Access. Penulis memilih mengembangkan LKS disebabkan karena dalam proses pembelajaran TIK belum menggunakan LKS dan buku referensi yang dimiliki siswa juga belum sepenuhnya dapat membantu siswa dalam pemahaman materi.

c. Analisis karakteristik siswa

Dalam penelitian ini penulis lebih menekankan analisis karakteristik siswa pada minat siswa terhadap pengembangan LKS, LKS seperti apa yang dinginkan siswa serta cara belajar TIK yang disukai siswa.

Terkait dengan data minat siswa terhadap pengembangan LKS, siswa yang memerlukan LKS dalam proses pembelajaran TIK adalah sebesar 92\%. Data tersebut menunjukkan bahwa hampir semua siswa memiliki minat terhadap pengembangan LKS yang dapat digunakan sebagai sumber belajar tambahan khususnya untuk materi Microsoft Access.

Terkait dengan data LKS seperti apa yang diinginkan siswa, sebesar 78\% siswa menyukai LKS yang didahului penjelasan teoritis, sebesar 94\% siswa menyukai LKS yang dilengkapi dengan langkah kerja yang jelas, sebesar 19\% siswa menyukai LKS yang dilengkapi dengan soal-soal teori saja dan sebesar $87 \%$ siswa menyukai LKS yang dilengkapi dengan soal praktikum. Data tersebut menunjukkan bahwa lebih banyak siswa menginginkan LKS yang dikembangkan diawali dengan penjelasan teoritis terlebih dahulu, dilengkapi dengan pemaparan langkah pengerjaan suatu materi yang jelas, serta dilengkapi dengan soal-soal teori maupun soal-soal pratikum.

Terkait dengan data cara belajar TIK yang disukai siswa, persentase siswa yang menyukai cara belajar bersifat teoritis saja hanya sebesar 3\%, sebesar $17 \%$ 
siswa menyukai cara belajar yang bersifat praktek saja, dan sebesar $96 \%$ siswa yang menyukai cara belajar yang menggabungkan antara teori dan praktek. Data tersebut menunjukkan bahwa siswa lebih menyukai cara belajar TIK yang diawali dengan penjelasan teori terlebih dahulu oleh guru, yang kemudian dilanjutkan dengan kegiatan praktek.

Dari hasil analisis karakteristik siswa tersebut, maka LKS yang dikembangkan dilengkapi dengan pemaparan materi yang diawali penjelasan teori terlebih dahulu, kemudian dilanjutkan dengan penjelasan langkah kerja suatu materi yang dapat dipraktekkan langsung oleh siswa. Selain itu, LKS juga dilengkapi dengan soal-soal obyektif dan soal-soal pratikum. Untuk membantu guru dalam melakukan proses penilaian terhadap soal-soal latihan tersebut, maka LKS dilengkapi dengan kriteria penilaian serta pembobotan soal.

d. Menetapkan Kompetensi Dasar dan Indikator

Penetapan Kompetensi Dasar dan Indikator pada pengembangan LKS ini dilakukan berdasarkan silabus yang digunakan di sekolah tersebut. Materi pada Microsoft Access dibagi menjadi empat judul LKS. Adapun judul-judul dari LKS tersebut adalah Prinsip Dasar Database, Merancang dan Mengedit Tabel Database, Query Dalam Database dan Membuat Serta Memodifikasi Form dan Report Dalam Database.

\section{Langkah Pengembangan}

Langkah pengembangan yang dilakukan pada proses pengembangan draft adalah sebagai berikut.

a. Menetapkan strategi pengorganisasian isi pembelajaran

Strategi pengorganisasian isi pembelajaran yang ditetapkan mengacu pada pemilihan isi, penataan isi, dan pembuatan sintesis. Pemilihan isi pembelajaran didasarkan atas kurikulum yang berlaku pada sekolah tersebut. Penataan isi dilakukan dengan cara menyajikan materi dari yang bersifat umum menuju ke materi yang bersifat khusus, sedangkan pembuatan sintesis dilakukan dengan mengurutkan tiap-tiap materi yang memiliki hubungan satu dengan yang lainnya. 
b. Menetapkan strategi penyampaian isi pembelajaran

Strategi penyampaian isi pembelajaran yang ditetapkan didasarkan atas komponen-komponen seperti media, interaksi pebelajar dengan media, serta bentuk belajar. Bentuk belajar yang digunakan dalam menyampaikan isi pembelajaran adalah pembelajaran secara klasikal dengan menggunakan metode demonstrasi, dimana proses belajar mengajar lebih banyak dilakukan di laboratorium komputer. Media yang digunakan dalam proses penyampaian materi adalah LKS dan komputer, sehingga diharapkan dapat terjadi interaksi langsung antara siswa dengan media yang digunakan.

c. Menetapkan strategi pengelolaan pembelajaran

Strategi pengelolaan pembelajaran yang dilakukan mencakup pada penjadwalan proses pembelajaran, pembuatan catatan kemajuan siswa, serta pengelolaan motivasi siswa. Strategi pembelajaran yang telah ditetapkan digunakan sebanyak empat kali pertemuan sesuai dengan jadwal yang telah ditentukan. Pemberian motivasi terhadap siswa dilakukan selama proses pembelajaran. Salah satu cara yang dilakukan untuk memotivasi siswa yang mengalami kesulitan dalam belajar adalah dengan memberi bimbingan secara individu. Pada akhir pertemuan dilakukan penilaian terhadap hasil belajar siswa dengan menggunakan LKS yang dikembangkan.

Pada tahap penyusunan draft, LKS Microsoft Access yang dikembangkan terdiri dari komponen-komponen berikut.

1. Kata pengantar

2. Daftar isi

3. Struktur LKS

- Judul LKS

- Standar Kompetensi (SK), Kompetensi Dasar (KD), dan Indikator Hasil Belajar (IHB)

- Petunjuk belajar

- Uraian materi

- Soal-soal latihan

- Penilaian 
- Daftar pustaka

4. Kunci Jawaban

Pada tahap tinjauan ahli dan uji coba, yang bertindak sebagai ahli isi sekaligus ahli media adalah Ibu Ketut Agustini, S.Si, M.Si dan Bapak Made Windu Antara Kesiman, ST, M.Sc, sedangkan yang bertindak sebagai ahli desain adalah Ibu Dra. Ni Ketut Sri Utami dan Bapak Nyoman Sudi Mahayasa, ST, M.Pd yang sekaligus sebagai pemilik percetakan CV. Sarasija Grafika. Pada tahap ini penulis mengalami beberapa kali proses perbaikan dan uji coba.

Berdasarkan hasil analisis data respon siswa, skor tertinggi ideal yang diperoleh adalah 100, sedangkan skor terendah ideal yang diperoleh adalah 20. Dari skor tertinggi ideal dan skor terendah ideal tersebut diperoleh MI sebesar 60 dan SDI sebesar 13,33. MI dan SDI tersebut kemudian dikonversi berdasarkan kriteria penggolongan respon siswa, sehingga didapatkan hasil seperti pada tabel 4 .

Tabel 4. Pedoman Konversi Respon Siswa

\begin{tabular}{|l|l|}
\hline Kriteria & Kategori \\
\hline $79,995 \leq \bar{X}$ & Sangat positif \\
\hline $66,665 \leq \bar{X}<79,995$ & Positif \\
\hline $53,335 \leq \bar{X}<66,665$ & Ragu-ragu \\
\hline $40,005 \leq \bar{X}<53,335$ & Negatif \\
\hline $\bar{X}<40,005$ & Sangat negatif \\
\hline
\end{tabular}

Rata-rata kelas untuk skor respon siswa yang diperoleh adalah 82,05. Ratarata tersebut menunjukkan bahwa respon siswa terhadap pengembangan LKS untuk materi Microsoft Access berada pada kategori sangat positif. Respon sangat positif tersebut menunjukkan bahwa LKS yang dikembangkan dapat membuat siswa merasa senang dan merasa lebih termotivasi dalam belajar Microsoft Access. Beberapa hal yang menjadi alasan siswa merasa senang dan merasa lebih termotivasi dalam belajar Microsoft Access dapat dilihat dari beberapa indikator diantaranya adalah materi yang dipaparkan menjadi lebih jelas, langkah-langkah pengerjaan suatu materi mudah dipahami, contoh-contoh yang diberikan dikaitkan dengan kehidupan sehari-hari, soal-soal latihan yang sesuai dengan tingkat 
kemampuannya, soal-soal latihan yang dapat mengukur tingkat pemahamannya terhadap materi, adanya soal-soal praktikum, adanya kriteria penilaian yang jelas, dapat menuntun siswa belajar mandiri serta dapat menambah wawasan bagi siswa.

\section{PENUTUP}

Berdasarkan hasil analisis data dan pembahasan pada penelitian pengembangan Lembar Kerja Siswa (LKS) untuk materi Microsoft Access maka dapat disimpulkan sebagai berikut.

1. Pengembangan Lembar Kerja Siswa (LKS) untuk materi Microsoft Access di kelas XI SMA Negeri 3 Singaraja dirancang dan diimplementasikan dengan menggunakan model pengembangan Dick and Carey. LKS Microsoft Access yang dikembangkan dengan model Dick and Carey tersebut merupakan LKS yang dapat digunakan untuk belajar mandiri oleh siswa, sehingga LKS tersebut dapat dimanfaatkan siswa sebagai sumber belajar dengan atau tanpa bimbingan guru dalam mencapai tujuan pembelajaran.

2. Respon siswa terhadap Pengembangan Lembar Kerja Siswa (LKS) berada pada kategori sangat positif, sehingga LKS tersebut layak untuk diujikan secara eksperimen. Respon sangat positif tersebut menunjukkan bahwa LKS yang dikembangkan dapat membuat siswa merasa senang dan merasa lebih termotivasi dalam belajar Microsoft Access.

Penelitian ini masih dapat dikembangkan sampai pada tahap pengukuran hasil belajar serta dapat dikembangkan menjadi sebuah penelitian eksperimen. Selain itu, LKS Microsoft Access ini juga dapat dikembangkan menjadi LKS yang bersifat interaktif serta dapat memperdalam cakupan materinya.

\section{DAFTAR PUSTAKA}

BNSP, 2007. "Panduan Penilaian Kelompok Mata Pelajaran Teknologi Informasi dan Komunikasi". Tersedia pada http://www.dikmenum.go.id/dataapp/kurikulum/3.\%20PANDUAN\%20PENILAIAN\%20KEL\%205\%20MAPEL/ CPanduan_Kel_Mapel_Ipteks.pdf (diakses tanggal 20 September 2009). 
Depdiknas, 2007. Materi Sosialisasi dan Pelatihan Kurikulum Tingkat Satuan Pendidikan (KTSP). Singaraja: Departemen Pendidikan Nasional.

Jauhar Fuad, 2009. "Telaah Teknologi Pembelajaran". Tersedia pada http://www.iaitribakti.ac.id/index.php?option=com content\&task=view\&id $=53 \&$ Itemid=78 (diakses tanggal 20 September 2009).

Kartini Kartono, 1996. Pengantar Metodologi Riset Sosial. Bandung: Mandar Maju.

Kusumayuningsih Ketut, 2005. Penerapan Media Komik Dalam Pembelajaran Fisika Sebagai Upaya Meningkatkan Motivasi Berprestasi Dan Penguasaan Konsep Siswa Kelas VIII C SMP Negeri 3 Kubutambahan Tahun Pelajaran 2005/2006. Skripsi (tidak diterbitkan). Jurusan Pendidikan Fisika, IKIP Negeri Singaraja.

Lia Kuswanto, 2005. Mahir dan Terampil Berkomputer TIK Untuk SMA Kelas XI. Bandung: Grafindo Media Pratama.

Oemar Hamalik, 1994. Kurikulum dan Pembelajaran. Jakarta: Rineka Cipta.

Padmiyoni, Nyoman. 2002. Penerapan Model Pembelajaran Kooperatif Tipe STAD Dalam Pembelajaran Fisika Sebagai Upaya Meningkatkan Hasil Belajar Siswa Kelas IC SLTP Negeri 6 Singaraja. Skripsi (tidak diterbitkan). Jurusan Pendidikan Fisika, IKIP Negeri Singaraja.

Romusha, 2007. "Lembar Kerja Siswa (LKS) Matematika Interaktif Model ELearning (Electronic Learning) Berbasis Web". Tersedia pada http://romusha-belajar.blogspot.com/2007/12/lembar-kerja-siswa-lksmatematika.html (diakses tanggal 20 September 2009).

Santyasa, I Wayan. 2009. "Metode Penelitian Pengembangan dan Teori Pengembangan Modul". Makalah disajikan dalam Pelatihan Bagi Para Guru TK, SMP, SMA, dan SMK, di Kecamatan Nusa Penida Kabupaten Klungkung, Universitas Pendidikan Ganesha Singaraja, Klungkung 12-14 Januari 2009.

Sugiyono, 2008. Metode Penelitian Pendidikan Pendekatan Kuantitatif, Kualitatif dan $R \& D$. Bandung: Alfabeta CV.

Suharsimi Arikunto, 2005. Manajemen Penelitian. Jakarta: PT. Rineka Cipta.

Sukardi, 2003. Metodologi Penelitian Pendidikan. Jakarta: PT. Bumi Aksara.

Sumadi Harta, Ketut. 2006. Implementasi Strategi Pemberian Tugas Dengan Pendekatan Konstruktivis Dalam Meningkatkan Hasil Belajar Matematika 
Siswa Kelas VIII SMPN 1 Sukasada. Skripsi (tidak diterbitkan). Jurusan Pendidikan Matematika, IKIP Negeri Singaraja.

Surya Dharma, 2008. "Strategi Pembelajaran dan Pemilihannya". Tersedia pada http://www.teknologipendidikan.net/wp-content/uploads/2009/10/14-kode 03-B5-Strategi-Pembelajaran-dan-Pemilihannya.pdf (diakses tanggal 20 September 2009).

Wina Sanjaya, 2008. Strategi Pembelajaran Berorientasi Standar Proses Pendidikan. Jakarta: Prenada Media.

Yeni, 2009. "Pengembangan E-learning yang efektif sesuai dengan karakteristik SMAN 2 Cimahi". Tersedia pada http://yeni.blog.upi.edu/category/4proposal-r-d/ (diakses tanggal 20 September 2009).

, 2009. "Pedoman Penyusunan LKS SMA". Tersedia pada http://125.163.204.22/download/admpendidikan/PEDOMAN\%20PENYUS UNAN_LKS.pdf (diakses tanggal 20 September 2009). 
JPTK, UNDIKSHA, Vol. 9, No. 2, Juli 2012 : 107 - 120 